\title{
Determination of Patulin in Apple Juice from Fuji Apples Stored in Different Conditions in Southern Brazil
}

\author{
Hudson Couto do Amparo ${ }^{1}$, Elissa Cavichon ${ }^{1}$, César Milton Baratto ${ }^{1}$, Eduardo César Tondo ${ }^{2} \&$ Jane Mary \\ Lafayette Neves Gelinski ${ }^{1}$ \\ ${ }^{1}$ Núcleo de Biotecnologia, Universidade do Oeste de Santa Catarina, Videira-SC, Brasil \\ ${ }^{2}$ Instituto de Ciência e Tecnologia de Alimentos, Universidade Federal do Rio Grande do Sul, ICTA, UFRGS \\ Correspondence: Jane Mary Lafayette Neves Gelinski, Núcleo de Biotecnologia, Universidade do Oeste de Santa \\ Catarina, UNOESC, Rua Paese, 198, Bairro Universitário, Videira-SC 89560-000, Brasil. Tel: 55-493-533-4479. \\ E-mail: jane.gelinski@unoesc.edu.br
}

Received: April 16, 2012 Accepted: May 8, 2012 Online Published: May 29, 2012

doi:10.5539/jfr.v1n3p54 URL: http://dx.doi.org/10.5539/jfr.v1n3p54

\begin{abstract}
The rapid increase in the global production of apples has led to improved monitoring and control of toxic substances present in apples and their derivatives. One of these toxic substances is patulin, a mycotoxin and secondary metabolite produced by different fungi species of the genera Penicillium, Aspergillus, Gymnoascus, Paecilomyces and Byssochlamys. This study evaluated patulin levels in juice produced from Fuji apples subjected to different temperature conditions and storage times in southern Brazil. The apples were divided into groups weighing $1 \mathrm{~kg}$ and stored at the following temperatures: $0^{\circ} \mathrm{C}, 5^{\circ} \mathrm{C}, 6.7^{\circ} \mathrm{C}, 19.5^{\circ} \mathrm{C}$ and $25^{\circ} \mathrm{C}$. Sub-samples of each group were processed to determine their patulin level by HPLC at the following intervals: 0 (control group), 7, 14 and 21 days. After 28 days of storage at all temperatures, the apples could not be analyzed due to their deterioration. The results indicated that at all temperatures; there was variation in the patulin levels. The smallest patulin value was observed in apple juice stored at $19.5^{\circ} \mathrm{C}$ and $25^{\circ} \mathrm{C}$.
\end{abstract}

Keywords: patulin, HPLC, packinghouse, apple

\section{Introduction}

Elimination of patulin from apple juice is in the interest of public health and the manufacturing process because patulin reduces the safety and the quality of concentrated apple juice. The world production of concentrated apple juice in 2008/09 reached 1,367 million tons (USDA. (2009). China is the biggest concentrated apple juice producer, with approximately $45 \%$ of the total produced. Whole apple exports in 2011/12 reached 5.6 million metric tons globally (USDA, 2011). Farms in European countries and the United States use particular and traditional methods to produce whole apples, apple cider (a natural non-pasteurized juice), hard cider (derived from apple cider), and other products such as applesauce. The increase in apple and apple juice production has stimulated the implementation of better quality control, especially with regard to toxic substances that are health risks to consumers.

In agribusiness, the contamination of apples with patulin-producing fungi is of greater concern than contamination of other food products (Drusch \& Ragab, 2003; Moake, Padilla-Zahour, \& Worobo, 2005), mainly due to the higher rates of consumption of apples and their derivatives. Deterioration is very difficult to avoid, even when the fruit is stored at very low temperatures (Jackson et al., 2003). The reduction of patulin levels in apple juice is important not only because of the effect caused by the toxin but also due to commercial issues, as it is an important differential in the quality of the concentrated apple juice. The maximum allowable concentration for the contaminant patulin in apple juice and apple products is $50 \mu \mathrm{g} / \mathrm{kg}$ (Commission of the European Community, 2003). Fungi growth and consequent patulin production may be influenced by storage conditions, and temperature control is one of the most important factors for the prevention of patulin contamination.

The mycotoxin patulin is a secondary metabolite produced by different species of fungi in the genera Penicillium, Aspergillus, Gymnoascus, Paecilomyces and Byssochlamys. P. expansum is the most important patulin producer (Pitt \& Hocking, 1997). The chemical name of patulin is [4-hydroxy-4-H-furo(3,2-c)pyran-2(6H)-one]; it is a lactone of the polyketide group with a molecular weight of $150.12 \mathrm{~g} / \mathrm{mol}$. Current studies suggest that patulin 
may cause DNA damage and apoptosis in murine cells (Saxena, 2009). In the present study, patulin levels were evaluated in juices processed from post-harvest industrial class Fuji apples stored in different temperature conditions.

\section{Method}

\subsection{Sample Collection}

Fuji variety apples from the same industrial packinghouse batch were collected in September 2010 in the state of Santa Catarina in southern Brazil. All apple samples were obtained under similar conditions (no washing and with natural microbial charge) and were from the same orchard.

\subsection{Sample Preparation}

Apples were obtained in a $300 \mathrm{~kg}$ lot from a juice industry packinghouse. The patulin level was registered as 131 $\mathrm{ppb}$. Five fractions of $1 \mathrm{~kg}$ each of unwashed apples with some physical damages and no rotten parts were placed in semi-open plastic bags (polyethene) and stored at the following temperatures: $0^{\circ} \mathrm{C}$ (inside cold storage chamber), $5^{\circ} \mathrm{C}$ (inside BOD Incubator), $6.7^{\circ} \mathrm{C}$ (inside refrigerator), $19.5^{\circ} \mathrm{C}$ (at room temperature), $25^{\circ} \mathrm{C}$ (inside BOD Incubator). Samples of each fraction ( $\min .150 \mathrm{~g}$ and max. $160 \mathrm{~g}$ ) were collected and analyzed for patulin levels at the following intervals: 0 (control group), 7, 14, 21 and 28 days.

\subsection{Juice Preparation for Patulin (PAT) Analysis}

At each interval, the fractions were visually evaluated. The apples were cut into slices and crushed by a processor to obtain the fruit juice. The juice was heated at $30^{\circ} \mathrm{C}$ with stirring for $30 \mathrm{~min}$ and treated with $20 \mathrm{ppm}$ pectinase (Pectinex ${ }^{\circledR}$, YieldMASH, Novozymes) to reduce viscosity and to facilitate filtration. The filtrates were then re-heated under agitation to $80^{\circ} \mathrm{C}$. Each sample was passed through a filter paper (Whatman $\mathrm{n}^{\circ} 4$ ) and frozen at $-18^{\circ} \mathrm{C}$ until PAT analysis.

\subsection{Patulin Analysis}

Patulin analysis was performed according to the AOAC Official Method 995.10 (AOAC, 1995) using an isocratic high performance liquid chromatography apparatus with UV, DAD detector $(276 \mathrm{~mm})$, AUFS sensitivity, and column C-18 (Agilent Technologies 1100 series HPLC, USA). The apparatus was balanced with acetonitrile-HPLC-grade water $(1: 99 \mathrm{v} / \mathrm{v})$ in the mobile phase $(0.8 \% \mathrm{v} / \mathrm{v})$. Forty microliters of each sample were injected and eluted with a flow rate of $1.5 \mathrm{ml} / \mathrm{min}$ and a retention time of $15 \mathrm{~min}$. The limit of detection was 10 $\mu \mathrm{l} / 1$.

\subsection{Standard Solution and Calibration Curves for PAT}

A standard solution was prepared by dissolving $5 \mathrm{mg}$ of pure crystalline PAT (Sigma Chemical Co., USA) in $10 \mathrm{ml}$ of distilled water (stock solution 1). Stock solutions were prepared by diluting the stock solution 1 . The standard solutions were kept frozen at $-18{ }^{\circ} \mathrm{C}$ until use. The peak areas were calculated over the calibration curve by subtracting the sample area values from the area values of the controls.

Each analysis was carried out in triplicate for each sample. The mean values are given in Table 1 after statistical analysis of average.

\section{Results}

Apples stored at $0^{\circ} \mathrm{C}$ and at $6.7^{\circ} \mathrm{C}$ before juice extraction exhibited a slightly rigid structure, a slightly fermented or acidic odor, and growth of the green filamentous fungus Penicillium expansum. After 28 days, the fruits had a strongly acidic odor accompanied by total loss of firmness, which made juice extraction and further analysis unfeasible (Figure 1). In the samples stored at $19.5^{\circ} \mathrm{C}$ and $25^{\circ} \mathrm{C}$, no fungus was detected, but there was similar deterioration and acidic odor. Different levels of patulin were observed at all temperatures. At $5^{\circ} \mathrm{C}$, the patulin levels rose considerably from day 14 to day 21 , with an average value twice as high as the level at day 0 . Patulin levels were lowest juice processed from apples stored at $19.5^{\circ} \mathrm{C}$ and $25^{\circ} \mathrm{C}$. The lowest observed experimental value of patulin, $11 \mu \mathrm{g} / \mathrm{l}$, was found in the samples stored at $25^{\circ} \mathrm{C}$ for 7 days (Table 1 ). 


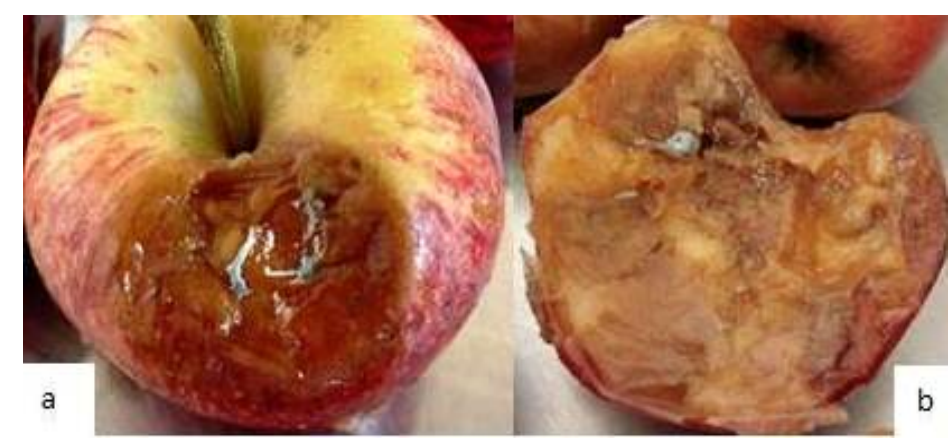

Figure 1. Apples $(\mathrm{a}, \mathrm{b})$ after 28 days of storage

Table 1. Levels of patulin in apple juice stored at different temperatures and for different lengths of time

\begin{tabular}{lllllllll}
\hline $\begin{array}{l}\text { Temp }{ }^{\circ} \mathrm{C} \\
\text { (average) }\end{array}$ & \multicolumn{3}{l}{ Days/levels of patulin $(\mu \mathrm{g} / \mathrm{l})$} & \multicolumn{4}{l}{ Statistic Analysis } \\
& 0 & 7 & 14 & 21 & Patulin & SD & $\mathrm{CV}$ \\
& Control & & \multicolumn{7}{c}{ Average } \\
& & & & & & \\
\hline 0 & 131 & 166 & 82 & 114 & 123 & 35 & 28 \\
5 & 131 & 29 & 425 & 460 & 261 & 214 & 82 \\
6,7 & 131 & 102 & 211 & 42 & 122 & 70 & 58 \\
19,5 & 131 & 34 & 38 & 10 & 53 & 53 & 100 \\
25 & 131 & 11 & 12 & 0 & 39 & 62 & 161 \\
\hline
\end{tabular}

$\mathrm{SD}=$ standard deviation; $\mathrm{CV}=$ coeficiente of variation.

\section{Discussion}

At all temperatures evaluated in this study, high patulin levels-with an average above of $50 \mu \mathrm{g} / \mathrm{kg}$-were observed, demonstrating that patulin can be produced in apples stored at a variety of temperatures. Although storage at $0^{\circ} \mathrm{C}$ is adequate for preservation of fruits prior to processing, the temperature must be closely monitored and controlled. The presence of patulin was evident in apples stored at $25^{\circ} \mathrm{C}$, but higher patulin levels were expected in this setting because the temperature is more conducive to fungi growth and patulin production. During the study, apples were stored in semi-open plastic bags, which created oxygen-reduced conditions. Some studies have indicated that the main factors affecting patulin production are temperature and oxygen concentration. However, the modulation of patulin production in response to changes in temperature or oxygen availability is dependent on the fungus lineage (Baert et al., 2006, 2007). The stress induced by lowering either the temperature or the oxygen level can stimulate patulin production, but concurrent changes in these variables do not necessarily have a synergistic effect on toxin production, as the combination of low temperatures and low levels of oxygen can also reduce patulin levels. Penicillium is a fungus found in internal environments. Due to its high humidity and mild temperatures, the packing house environment favors fungus growth; the conditions in this setting are similar to those used in our study. In Brazil, 3- to 7-day delays occur between apple harvesting and juice processing, and storage during this time is often unrefrigerated. These factors also favor fungi development. The industries that are capable of fast fruit processing follow the guidelines of the Codex, and processing takes place less than $18 \mathrm{~h}$ after harvesting (Sant'Ana, Rosenthal, \& Massaguer, 2008). According to Morales et al. (2007), the reduction of storage time to a minimum is a critical point, as it is a limiting factor for patulin accumulation, and the industries should guarantee the quality of the apples prior to processing. Other methods can be used to alter patulin levels. As noted by Sant'Ana, Rosenthal and Massauguer (2008), centrifugation, bentonite, filtration with diatomaceous earth and pectinase have been studied for their potential use in reducing PAT levels during apple juice production, but this least reduces the PAT levels by only 4.5\%. Ross et al. (1998) observed that patulin was metabolized by other microorganisms, such as yeast and bacteria that replaced filamentous fungi. Fuch et al. (2008) also demonstrated the detoxification of mycotoxins by two lactic acid-producing bacteria; in this in vitro experiment, the bacteria reduced the concentration and toxicity of patulin and ochratoxin. The low 
cost of raw material and the necessity of industrial cost reduction make it difficult to improve the treatment of "industrial" fruit or to implement methods that could reduce fungal contamination, such as washing with sanitizing products. Fruit washing does not guarantee patulin removal; on the contrary, washing can increase patulin diffusion in the fruit, especially if there is any fruit damage (Fuch et al., 2008). In Brazil, apples for fresh consumption are stored at $0^{\circ} \mathrm{C}-1{ }^{\circ} \mathrm{C}$, and as in most other countries, there is no temperature-regulated storage of apples that are used to produce apple juice. Further studies of the effects of storage temperature and fruit quality on patulin production will guide the development of methods that reduce patulin in industrial apples prior to their processing.

\section{References}

AOAC. (1995). Official Method of Analysis. 16th Ed. March 1996 Supplement, AOAC INTERNATIONAL, Gaithersburg, MD, sec. 995. 10.

Baert, K., Devlieghere, F., \& Flyps, H (2006). Occurrence patulin in organic, conventional, and handcrafted apple juices marketed in Belgium. J. Food Prot., 69, 1371-1378.

Baert, K., Devlieghere, F., Flyps, H., \& De Meulenaer, B. (2007). Influence of storage conditions of apples on growth and patulin production by Penicillium expansum. I. J. Food Microbiol, 119, 170-181, http://dx.doi.org/10.1016/j.ijfoodmicro.2007.07.061.

Commission of the European Community. (2003). Commission Directive 1425/2003. amending Regulation (EC) No 466/2001 as regards patuling. Official Journal of the European Community Legislation, L203, 13.

Drusch S., \& Ragab, W. (2003). Mycotoxins in fruits, fruit juices, and dried fruits. J. Food Prot., 66, 1514-27. http://dx.doi.org/10.1016/j.foodchem.2005.09.043

Fuchs, S., Sontag, G., Stidl, R., Ehrlich, V., Kundi, M., \& Knasmuller, S. (2008). Detoxification of patulin and ochratoxin A, two abundant mycotoxins, by lactic acid bacteria. Food Chem. Toxicol, 46, 1398-1407. http://dx.doi.org/10.1016/j.fct.2007.10.008.

Jackson, L. S., Beacham-Bowden, T., Keller, S. E., Adhikari, C., Taylor, K. T., Chirtel, S. J., \& Merker, R. I. (2003). Apple quality, storage and washing treatments affect patulin levels in apple cider. $J$ Food Prot., 66(4), 618-624. Retrieved from http://www.foodprotection.org/publications/journal-of-food-protection .

Moake, M. M., Padilla-Zahour, O. I., \& Worobo, R. W. (2005). Comprehensive review of patulin control methods in foods. Comprehensive Reviews in Food Science and Food Safety, 4, 8-21. http://dx.doi.org/10.1111/j.1541-4337.2005.tb00068.x.

Morales, H., Marín, S., Centelles, X. Ramos, A. J., \& Sanchis V. (2007). Cold and ambient deck storage prior to processing as a critical control point for patulin accumulation. Int. J. Food Microbiol, 116, 260-265. http://dx.doi.org/10.1016/j.ijfoodmicro.2007.01.004

Pitt, J. J., \& Hocking, A. D. (1997). Fungi and Food Spoilage. Blackie Academic \& Professional, London, 593.

Ross, G. U., Taniwaki, M. H., Sabino, M. et al. (1998). Produção de patulina em maçã (Malus domestica Borkhausen), cultivares Gala e Fuji inoculadas com Penicillium spp. Ciênc. Tecnol. Aliment, 18, 63-67. http://dx.doi.org/10.1590/S0101-20611998000100014.

Sant'Ana, A. S., Rosenthal, A., \& Massaguer, P. R. (2008). The fate of patulin in apple juice processing: A review. Food Res. Int., 41, 441-453.

Saxena, N., Ansari, K. M., Kumar, R. A., Dhawan, A., Dwivedi, P. D., \& M. Das. (2009). Patulin causes DNA damage leading to cell cycle arrest and apoptosis through modulation of Bax, p53 and p21/WAF1 proteins in skin of mice. Toxicology and Applied Pharmacology, 234, 192-201. http://dx.doi.org/10.1016/j.taap.2008.09.033.

USDA. (2009). Foreign Agricultural Service. Apple Juice, Concentrate Production, Supply, and Distribution in Selected Countries.

USDA. (2011). Fresh Deciduous Fruit (Apples, Grapes, \& Pears): World Markets and Trade. 